\title{
An Analysis of Chinese Cultural Confidence in the "Belt and Road" Strategy_ B Based on the Vision of a Community with Shared Future for Mankind Contained in the Communist Manifesto
}

\author{
Zhiqian Ji \\ Jiaxing College, Jiaxing, Zhejiang 314000 \\ Email: $1205290944 @$ qq.com
}

\begin{abstract}
After the 18th National Congress of the Communist Party of China, the Party Central Committee stood for the times and proposed forward-looking strategies such as the "Belt and Road" and cultural confidence. Cultural confidence is based on the profound heritage of our own excellent traditional culture, and the advanced socialist culture condensed in long-term practice. Its role in the "Belt and Road" strategy cannot be underestimated. Use culture to communicate, to draw in our relationship with other countries. It is not only in line with the vision of a community with shared future for mankind contained in the Communist Manifesto, but also able to demonstrate the demeanor of a major country and ensure the smooth progress of the "Belt and Road" strategy.
\end{abstract}

Keywords: The Belt and Road, Cultural confidence, The community with shared future for mankind

\section{Introduction}

The report of the 19th National Congress of the Communist Party of China stated that "culture is the soul of a country and a nation." A country that is not confident about culture is empty and soulless. Cultural confidence is reflected in the awe of recognition of the depth of cultural development, value connotation and system theory, rather than being arrogant and complacent. And the implementation of the "Belt and Road" strategy requires exchanges and communication between the countries along the line, and culture plays a role in connecting and linking up and down. Therefore, we are confident in our own culture, let the culture take the lead, and let the people in the countries along the line communicate with each other for common development and progress. Towards a common vision Based on the flexible use of Marxism by China in this era, the "community with shared future for mankind " is a beautiful vision ${ }^{[1]}$.

\section{The vision of a community with shared future for mankind contained in the Communist Manifesto}

The report of the 19th National Congress of the Communist Party of China proposes that People of all countries should work together to build a community with a Shared future for mankind and build an open, inclusive, clean and beautiful world of lasting peace, universal security and common prosperity. We should respect each other, consult on an equal footing, firmly reject the cold war mentality and power politics, and take a new path of state-to-state relations featuring dialogue rather than confrontation and partnership rather than alliance. Although this concept of a community of Share future for mankind does not appear directly in the Communist Manifesto, Marx and Engels pointed out that "with the development of the bourgeoisie, with the realization of free trade and the establishment of a world market, with industrial production and living conditions adapted to it, ethnic isolation and opposition between peoples has disappeared." As the world gradually becomes a whole, the ideal of communism will also have a bright future. "Instead

Copyright (C) 2020 Zhiqian Ji

doi:10.18282/le.v9i5.1204

This is an open-access article distributed under the terms of the Creative Commons Attribution Non-Commercial License

(http://creativecommons.org/licenses/by-nc/4.0/), which permits unrestricted non-commercial use, distribution, and reproduction in any medium, provided the original work is properly cited. 
of the old bourgeois society where class and class opposition existed, there would be such a union, where the free development of everyone is a condition for the free development of all people." We can see that its ideal of free and comprehensiveness development of human beings has a certain continuity in connotation with the community with shared future for mankind, and has certain inheritance and continuity in the development process. The putting forward of the idea of the community with shared future for mankind is a Chinese modernization of the idea of a free-man union by contemporary Chinese Marxists. It is an inevitable inheritance choice made by China based on China's current national conditions, and it is also a Chinese method that is fundamentally different from western monopoly capitalism for the development of the world and the solution of globalization.

\section{Background proposed by the Belt and Road Initiative}

The formulation of any strategy was not accomplished overnight. With the deepening of the globalization of the world economy and the further strengthening of regional economic integration, it has also been accompanied by the rise of local trade protectionism and new frictions ${ }^{[2]}$.

The increasing strength and increasing influence of China's comprehensive national strength has triggered a new round of adjustments in geostrategy. In order to curb China's further strength, the United States has proposed the "AsiaPacific Rebalancing Strategy" in order to safeguard its interests and influence in the Asia-Pacific region, and formulated trade rules and standards based on the level of economic development of developed countries in an attempt to exclude China and other developing countries. It can also be seen that China's rapid development has also attracted widespread attention from the international community, and some "China threat theories" have also been clamoring, especially surrounding countries have concerns and concerns about China's rise. After more than 40 years of reform and opening up, China has achieved great achievements and is also among the ranks of upper-middle income countries. In 2014 , General Secretary Xi Jinping announced that China's economy has entered a "new normal", the economic growth rate has slowed down, and the economic structure urgently needs to be optimized and upgraded. The weakening of the traditional troika's pulling ability requires new economic growth points to solve the existing problems. At the same time, in the early days of reform and opening up, the eastern coastal areas benefited from the geographical location and related policies and enjoyed the dividends of reform and opening up, but some central and western regions and remote areas were relatively lagging behind. The problem of imbalanced regional development is more prominent. Although our government has found and proposed some measures to improve this problem, this problem still persists. From the historical point of view, as early as the Qin and Han dynasties, the "Maritime Silk Road" with the South China Sea as the center has been established, passing through the Indo-China Peninsula and the South China Sea Islands, crossing the Indian Ocean, reaching the destination of Europe and Africa. The earliest known sea route. Later in the Western Han Dynasty, Zhang Jian's mission to the Western Regions took the first step of the "Onshore Silk Road". Through the "Silk Road", Chinese and Western cultures have been given opportunities for exchange, and foreign trade activities have also continued. The establishment of the "Silk Road" has become a bridge for friendly exchanges between China and neighboring countries.

\section{The role of cultural confidence in the Belt and Road Initiative}

In 2013, when visiting Kazakhstan and Indonesia, General Secretary Xi Jinping proposed the "Belt and Road" initiative. Looking at it now, this initiative demonstrates the far-sighted strategic vision of the Party Central Committee and reflects China's responsibility and responsibility in the great vision of building a "community with shared future for mankind". In the connotation of the "Belt and Road" initiative, the Chinese traditional political concepts are repeatedly emphasized: the world for the common, the world is great, the people are the foundation, the faith and harmony, and good neighborliness and benevolence. These ideas come from the excellent Chinese culture which has been passing down for thousands of years. As pointed out in the report of the 19th National Congress of the Communist Party of China, "Culture rejuvenates the country and promotes prosperity. Without a high degree of cultural confidence and cultural prosperity, there is no great rejuvenation of the Chinese nation." The "Belt and Road" strategy fully reflects the cultural confidence of the Chinese nation walking on the road of rejuvenation. 


\subsection{Help to eliminate cultural misunderstandings and establish a good international image}

Due to differences in values, interests, and other factors between countries, some Western media have misinterpreted the "Belt and Road" initiative to a certain extent, considering the "Belt and Road" as the "China's Marshall Plan", and feel that this initiative is a change China is trying its current situation has reshaped the international situation and rendered the Belt and Road Initiative a strong ideological color. At the same time, there are realistic border conflicts between China and India, and disputes with Japan on the Diaoyu Island issue. China's geopolitical environment is as thin as ice. Provoked by the Western nations led by the United States, some Southeast Asian countries have developed some anti-China sentiments, suspecting that the Confucius Institute in China is an ideological infiltration and cultural invasion. However, compared with the ideological and conditional aid provided by western developed countries, the "Belt and Road" initiative has no additional conditions and ideology. In such a situation, we can only have a firm cultural confidence and let other countries in the world fundamentally understand the "Belt and Road" and Chinese culture. Knowing China can eliminate its misunderstandings about China, understand China's peaceful rise and development philosophy, and an open and inclusive heart of "comers are all guests." From questioning misunderstandings to cooperation and win-win, establish a positive international friendly image ${ }^{[3]}$.

\subsection{Help promote economic development and share development results with countries along the route}

All aspects of social development are supported by strong economic support. The "Belt and Road" strategy not only connects China economically with other countries along the route, but also helps each other understand each other's culture. Promoting economic cooperation requires cultural communication and cooperation, and cultural confidence is the prerequisite for cultural communication. On the basis of mutual equality, the countries along the Belt and Road understand each other's cultural spirit, respect each other's cultural practices, and carry out exchanges and cooperation to a deeper level without disturbing the cultural traditions of the countries along the Belt and Road. We have an excellent Chinese culture for 5,000 years, so we don't need to be arrogant or overly admired. We must have confidence in our own culture. Economic development drives the advancement of culture, and cultural prosperity promotes economic development. Cultural understanding and mutual assistance can not only reduce friction and misunderstanding among the countries along the route, but also speed up the implementation of some excellent ideas, promote the optimization of industrial resources, and share development results with the countries along the route. In addition, China pursues an independent foreign policy of peace and deepens its relations with neighboring countries in accordance with the principle of sincerity and compassion and the principle of goodwill with neighbors and neighbors. Therefore, we are pursuing the "Belt and Road" strategy not to be evil with our neighbors, nor to the Chinese-style economic expansion, nor to the "China Marshall Plan". This is based on our confidence in our own culture and the requirement for stable economic development. It is also the only way to build a community with shared future for mankind through the mutual interaction of cultures and economic development to the people's hearts.

\subsection{Conducive to promoting excellent Chinese culture and driving the development of related cultural industries}

The world's first "Confucius Institute" was established in Seoul, South Korea in 2004. As of December 2019, 550 Confucius Institutes and 1172 Confucius Institutes have been established in 162 countries and regions. At the same time, 492,100 international students from 196 countries and regions are studying in China. Among them, students from countries along the "Belt and Road" have reached 260,600, accounting for 52.95\% of the total. Under the "Belt and Road" cooperation framework, exchanges and cooperation in the cultural field will help people in different cultures communicate with each other, learn from each other's excellent cultures, and make progress together. At the same time, with the rapid development of the Internet, some creative cultural industries in China are also developing rapidly. For example, the cultural and creative products independently developed by the cultural and creative experience camp of the Palace Museum, which is built by the Palace Museum, are popular at home and abroad for their rich cultural connotation, design and functions. Through these Chinese cultural innovations, foreign friends can see China's colorful culture and oriental lifestyle. Cultural confidence is not an empty slogan, but a recognition of one's excellent culture 
and its integration into all aspects of social production, giving new life. Through the "Belt and Road" strategy, we will continue to tap the depth of our culture, broaden it, combine culture with industry, and drive the development of the cultural industry. The cultural industry is not only a magnifying glass for us to observe the world, but also a new window for the world to understand China, and to allow China to integrate with the world, history and reality, and cultural and commercial exchanges.

\section{References}

1. Liu Yang. Research on the Role and Path of Cultural Confidence in the "Belt and Road" Initiative [J]. Journal of Lianyungang Vocational and Technical College, 2018, v.31; No.114 (01): 68-70.

2. Wan Xiuli, Shen Lingmin. Analysis of the value and manifestation of cultural self-confidence in the "Belt and Road" initiative [J]. Seeking Truth from Facts, No.262 (03): 102-107.

3. Wang Yu. The Contemporary Value of the Thought of the Community of Human Destiny Contained in the "Communist Manifesto" _ Thinking Based on the Belt and Road Initiative [J]. Chinese Character Culture, 2019(22):126-127. 